\title{
The concept of time management based on Ephesians 5:15-17 and relevance to contemporary Christian leaders
}

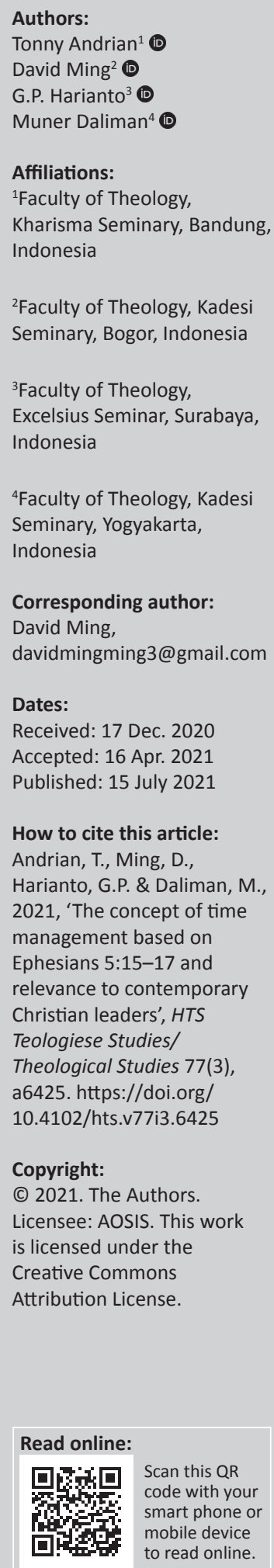

Generally, it is common knowledge that humans have the same time, 24 hours a day, seven days a week, 31 days a month, 365 days per year, but most of them do not know how to manage time and manage it to be something useful and effectively. That is because many people do not have the discipline in filling time. Those days are filled with things that are not directed, even worse is that filling the time of his or her life with things that damage life. Even though wasting time is not unwise because it is a waste of the opportunity God has given and the time that has passed will not return, meaning that if the opportunity is not used, then the opportunity will be lost. How important is to redeem the time, especially for contemporary Christian leaders because all must be accountable to God. This study uses a research library. Library research is a literature study that is carried out by using relevant and available reading sources related to the topics discussed in the research. Books or journal articles related to the topics discussed are used as sources of reading to better understand time management and its application at the personal and organisational levels. From the various reading sources used, the writer develops this scientific article, including giving comments or critical comments that are conveyed in various parts of the writing, especially in the conclusions.

Contribution: Time management is one of the basic skills needed to be successful in life, especially for contemporary Christian leaders. The findings of various studies based on Ephesians 5:15-17 indicated that time management enabled organisations or churches to learn to survive in the face of competition and resulted in success as Christian leaders.

Keywords: concepts; time management; relevance; Christian leaders; Ephesians 5:15-17.

\section{Introduction}

In general, every human being who lives in the world has the same time, 24 hours, seven days a week, 31 days a month, 365 days per year, but most of them do not know how to manage time and manage it so that it becomes something useful, effective and efficient (Wicak 2008:44). This is because many people do not have the discipline to pass the time. Their days are filled with things that are not directed, even more severe is those that fill the time of their life with things that destroy life, whereas wasting time is a sin because wasting the opportunity God has given and time that has passed will not come back, meaning that if the opportunity is not used, then the opportunity will be lost (Octavianus 1986:36). This is in line with what Sanders said that time can be lost, and it cannot be recovered, time cannot be saved because it is used. Time also cannot be postponed, and if it is not used productively, then time will be lost and cannot be recovered. For that, do not waste your time (Sanders 1974:96).

From the above statement on the importance of time management, the Bible also writes about the importance of the task of managing the time entrusted by God to his children. As one example, the creation story explains that Allah not only regulates the order of his creation, but also he arranged the time to create it, not only the universe and everything in it, but also time which is an inseparable part of God's creation. Thus, God's commandment to man (Gn 2:15) also implicitly includes the management of time. God's gift is not only material in the form of money, but time is also a gift from God that has been entrusted to humans. In other words, humans must be able to manage their time properly, because it is not only a financial problem that must be regulated and organised, but also a matter of time. One of the devil's tactics is to involve God's children in useless things that take up time (Rush 2002:153). Paul also calls on the church at Ephesus (Eph 5:15-17) to take advantage of their time because the days are evil. Evil is a state of the age that has been controlled by tyrannical

Note: Special Indonesian Collection: Philosophy, Culture and Theology, sub-edited by Busro Busro (Islamic State University Sunan Gunung Djati Bandung) 
powers so that it causes evil in a matter of hours, minutes, seconds so that it is difficult for everyone to live in righteousness (Calvin 1996:314). The purpose of Paul's advice to the church at Ephesus emphasised that they would be able to make good use of their time in the midst of the forces of evil so that the opportunities God gave them would not be in vain. For that everyone is responsible for the use of time, especially a spiritual leader must be able to streamline his or her life and manage his or her time well, so that the time he or she passes is used for a life that glorifies God. The great leader of the Israelites, Moses considered time to be a priceless staple, so he prayed for a wise heart and was taught to count the days, not years (Ps 90:12). A wise heart is a heart that 'knows the power of God's wrath'. To obtain a wise heart, humans need to be guided by God to ask to be taught so that the days of their life are filled with God's loyal love, not his wrath (Barth 1999:160).

The meaning of the verse above should change the thinking of church leaders today. For example, Augustine, one of the church fathers, for 15 years has spent his time with many women and is living in adultery. So much time was wasted by Augustine that he was converted at the age of 32 and worked for God. From the story, it reminds us how important the use of time is, so a leader must be careful in choosing his or her priorities. Church leaders must realise that time is their most valuable resource because the quality of a person's leadership is expressed as long as he or she leads and is filled with something that is effective and efficient (Sanders 1974:95). From this statement, it is evident how important the use of time is, especially for contemporary Christian leaders, because all must be accountable to God. The basic questions of time to answer are: What is meant by time? What about time management? How wise is the basis for the process of managing time? What is wise time management, as a pattern of increasing the effectiveness of the work of Christian leaders?

\section{Research methodology}

This study uses a descriptive literature method, which consists in a description and explanation of the problem from the data obtained (Surakhmad 1998:456). Meanwhile, the writing procedure begins with the search for materials in accordance with the subject matter, both from libraries and other media such as journals, magazines or the Internet. And the book that becomes the reference is Stephen Tong's Time and Wisdom because it contains time management from a biblical perspective, Oswald Sanders' spiritual leadership and Octavianus management and leadership according to God's revelation about the practice of time management with leadership. Also the book by Wicak and Jane Smith on the view of secular time management is used as a comparative material so that the data that have been obtained are analysed and finally outlined in the form of a scientific research.

\section{Result and discussion Definition of time}

A Chinese writer said, 'Time is something that is invisible, but so real'. Time is walking and passing between human legs. At bedtime, time is passing around the bed. This provides evidence to a person that consciously or unconsciously time has been used. Heidegger, one of the greatest German thinkers, said that humans must live authentically, in time. Jean Paul Sartre goes even further to say that states of being are swallowed up by non-existence. That is, life now can enjoy everything, but one day at death, everything is finished and there is nothing (Tjahyadi 2008).

The essence of time can be understood as follows. (1) Time is the essence of planning in the world that is related to the process. In this world, nothing but only Allah is eternal because He does not need the process. He is the One who exists from eternal to eternal. In contrast, everything that is created in the world undergoes a process, and in the human process, it takes time. That is why time is the essence of the process in the relative world. (2) Time is a reality related to space. Everything that Allah created has three of the most important elements: space, time and existence. Often there is a mistake in the way of thinking of humans because they only see space as a container for accumulating property and never see time as a place for humans to be wiser again. A wise person is sensitive to time, and time is in balance with space; this person will have tremendous power in his or her life (Tong 1990:31-36). (3) Time has a purpose, so the purpose of human life is not only to earn money and become famous, but to know Christ as Lord and Saviour and serve him by living and proclaiming his gospel.

In this regard, the statement that 'Time is money' is an imprudent statement. Time is not money. If time is money, then one can exchange time for money. An old Chinese proverb says 'an inch of time equals an inch of gold is worth, but an inch of gold cannot replace an inch of time'. If western people say 'Time is money', then eastern people (Chinese) say 'Time is money, but money is not time'. If time is not money, how do people perceive time? (1) Time is life. This is an important lesson for the life of every human being to realise how much time has been wasted in vain from young to old in his or her life, which is filled with an extramarital affair, without an orgy of doing the most important thing in this life. If humans really love themselves, they should begin to love the time that is in living alone; do not delay until tomorrow what can be done now; and do not wait until old age what can be learned in youth. (2) Time is opportunity. In Greek mythology, the god of opportunity is depicted with a bald head on the back and hair only in the front and has wings on his feet, so that the god of opportunity runs very fast. This god of opportunity rarely passes, so humans have to look for him if the god of opportunity passes and try to chase him, and he cannot possibly be caught because he has wings on his feet. Additionally, one could not catch him from behind because the back of the head was bald. Likewise, with opportunities that come before humans, do not waste them and catch them and do it fast. (3) Time is a record. All events that occur in the life of every human being are a history and of course it is a part that cannot be forgotten because it becomes a memory and a record for humans themselves (Tong 1990:37-38). 
Time, for the Greeks is divided into 64 tenses. English has 16 tenses. Indonesian does not recognise a system like this. The Greeks recognised two terms, namely: kairos and kronos, which have the following meanings. Kairos is the concept of time that makes a person effective and works harder. Kronos is the time that flows and lives by all the people in this world just like that. Time -24 hours a day - is circling and is lived continuously (Brown 1999:838). So the time of the chronos goes with the flow of life without any important moment in it.

\section{Time management}

The word management comes from the Italian word maneggiare, which more or less means to handle. In Latin, manus means hand or handle (Octavianus 1986:1). Terry said that management is a unique process, which consists of the following actions: Planning, Organising, Activating and Supervising, which are carried out to determine and achieve predetermined goals through the use of human resources and other resources (Sutedja n.d.:29).

Furthermore, Harbison and Myers classified management into three types, namely:

1. Patrimonial management. This is when a company is owned by a family and important positions in the company hierarchy are controlled by the members of the family.

2. Political management. A form of management in which important and basic positions in the organisation are held by those who have political relations based on loyalty to a certain political party.

3. Professional management. Strategic and important positions are left to those who have provided evidence of their abilities, capacities, expertise or in other words on the basis of the services and results they provide to the company (Harbison \& Myers 1998).

Management strategic techniques and the application of clear individual functions make the company's management performance more enthusiastic and also survive from competition as well as healthy competition, because these individuals show proficiency and loyalty to the company so that the company's performance increases. This is because, in essence, management functions as Planning, Implementation and Evaluation. However, the implementation of these basic functions can be developed flexibly according to the needs of the organisation. Dessler (Wiryopuro 2001:9) describes that the basic functions of management are: (1) Planning, which includes goal setting, action, developing rules and procedures, developing plans and making predictions; (2) Organising, which includes assignment, divisions, delegation of authority, and coordinating work; (3) Staffing, which includes employee recruitment, training and development; (4) Leading, which includes giving orders, maintaining employee motivation and morale; and (5) Controlling, which determines standards, making improvements if necessary.

\section{Ephesians}

The subject or theme of Ephesians is the church as the body of Christ. The subject of the description of Ephesians has two aspects, namely: regarding the wealth of the church in Christ (Ps 1-13) and about the practical consequences in the life of the church (Ps 4-6).

The theme of the epistle to Ephesians is found in Ephesians 3:4, which reads 'when you read it, you will know from it my understanding of the mystery of Christ'. The secret is the church of Christ. The church is a community that lives in such unity and love that it can be called the body of Christ. Speaking of the body definitely consists of several parts and functions. The church is to be the hand that does the work of Christ, the foot that is commanded and the mouth that speaks for him (Barclay 1983:101). That is why in Ephesians, we find two points. Firstly, Christ is God's instrument of atonement. Secondly, the church must introduce Christ to the world and it is within that church that all dividing walls must be broken down, both Jew and gentile are one in Christ.

\section{Exegesis of Ephesians 5:15-17}

\section{Text of Ephesians 5:15-17}

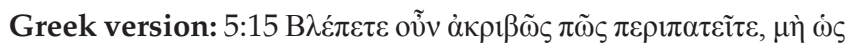

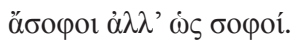

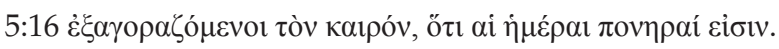

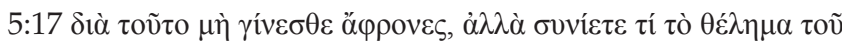
кupíov.

\section{Text of Ephesians 5:15-17}

KJ version: 5:16 See then that ye walk circumspectly, not as fools but as wise.

5:16 Redeeming the time, because the days are evil.

5:17 Wherefore be ye not unwise, but understanding what the will of the Lord is.

There are several things that are used to clarify and explain the meaning of Ephesians 5:15-17: the exegesis of some

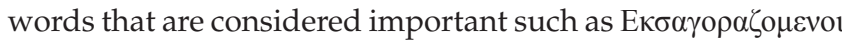
and Kaıpoб; some things that have to do with the discussion of these words; and examples of the concept of wisdom, time and the last part, of course, the conclusion of the word

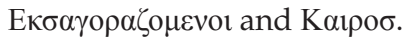

\section{Exegesis verses 15-17}

Verse 15: Paul begins the verse with the words 'therefore', which is Greek 'ouv'. This word clearly wants to show the relationship between verse 15 and the verses above or even very possibly with the whole of the previous chapters and verses. Because of the divisions in previous chapters Paul explained the difference between children of light who are obliged to live in love according to God's call (Eph 4:1; 5:28) and people who do not know God, namely the behaviour of 
the world, the flesh and the devil (Eph 4:1;5:28) (Stoot 2003:196). After expressing the above truth, he said 'because of that' he wanted to conclude and advise the congregation or believers to do something important. Paul goes on to say 'watch' carefully how you live. For 'Behold', he uses the Greek word 'B $\lambda \varepsilon \pi \varepsilon \tau \varepsilon$ translated as: Blepete' and the word ' $\beta \lambda \varepsilon \pi \varepsilon \tau \varepsilon \jmath^{\prime}$ ' used the present imperative verb (Wenham 1977:56). The present imperative is a command verb to continue an activity. So it can be translated as 'keep on watching', keep paying attention. So we can see accurately the spiritual relevance of all things of value, especially those of very high value that require careful, accurate and close attention. Paul also continues a statement, 'do not be like a fool, but like a wise person' (Greek: $\mu \varepsilon$ oб $\alpha \sigma o \pi \eta \circ)$. Paul meant that the church should not behave like ignorant people because by nature they are children of light. Their life should be wise, what is meant by wise is not only knowledge but also skills in life (Lincoln 1990:341). William Dyrness defines wisdom as a very practical art to be skilled and successful in life (Dyrness 2004:173).

According to John R.W. Stoot, a wise person has two important attitudes:

- Wise people know very well that time is very expensive, so they do activities that have added value (value added), are eternal, and not temporary.

- A wise person understands God's will by (1) becoming Christ-like and (2) reading his words because God's will is in his words (2 Tm 3:15). This is done to make us wise and stop from sin in our life (Stoot 2003:172).

Paul asks believers to act wisely, to be able to see and read situations and to know how to behave as well as to apply the knowledge they gain in their actions. In addition, Paul asks them to appreciate and love the time that fills their lives with divine ethics. Redeeming the time because the days are evil, so that he knows how to use this moment with responsibility to glorify God and try to understand God's will.

\section{Concept wisdom in Old Testament}

The word for wisdom in Hebrew is הוקמה for Israel. Wise is basically 'Fear of God', and it is an expression of the religion that the Israelites profess. This expression begins with the simplest religious element, a sense of trembling before his presence. It is the most complicated matters of obedience to laws and to worship him. Wise also has to do with very practical intelligence, wisdom and deep understanding to act with caution, so that people are successful and not deficient in life as well as in orderly, good behaviour and learning how to do what is good and right and fair. Wisdom is only obtained by relating to God and reading his Word, because the Word and practising the Word in daily life will make humans wise (Hill 1996:413-415).

\section{Concept wisdom in the New Testament}

The wisdom emphasised in the New Testament is $\Sigma$ or $11 \alpha$. $\Sigma$ oлn $\alpha$ in Greek culture means the wise, which represents extraordinary abilities. The focus of one's life practice is to do everything well. Wisdom talks about combining spirituality and living practices according to God's will. Jesus Christ as a source of wisdom, of course, teaches and instils a principle that is very important for humans, as evidenced in the lesson to love enemies and to bless (Lk 6:27-29). The teaching is very deep in its meaning and wisdom; how is it possible to love an enemy who hurts and to bestow blessings on him or her, but this is a reality that must be acieved, and here is the love and wisdom of Jesus Christ.

\section{Verse 16}

It turns out that verse 15 is continuous with verse 16 . Paul wants to state that the concrete behaviour of believers who understand God's noble purposes is to continuously use the available time, because we must be right to try to find and do God's will. The word ' $\varepsilon \varpi \xi \alpha \gamma o \rho \alpha \zeta o, \mu \varepsilon v o i$ ' is a combination of $\varepsilon \varpi \xi$ [to leave] and $\alpha \gamma o \rho \alpha \zeta \omega$ [to buy or to pay], whilst agora itself is a noun, which means market. So the noun agorazo literally means buying at the market. Eksagorazo was also used to mean ransom or pay for slaves. The prefix 'ex', according to E.F. Scott, shows great activity, that is, taking all opportunities that can be taken and calls to know oneself in the light of God's will, which is characteristic of a wise person who lives in fellowship with God (Earle 1983:321-322).

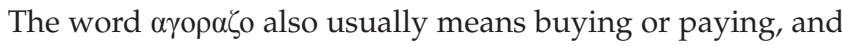
this word is usually used in the field of commerce whilst buying or redeeming a slave in the market. To denote 'redeeming', not only the word agorazo is used, but the word 'lv $\rho \omega \omega^{\prime}$, which is translated as lutro, also means to redeem or save sinners who have been redeemed in full. Gaal also has the meaning of redeeming, but what is redeemed here is not a human being, but land or fields are often used in the Old Testament (Bruce 1984:379).

Paul also asserts that the times or days that are wicked is full of trouble and pain. Paul gives further understanding that as children of God we should be able to take advantage of every opportunity and even have to buy as many opportunities as possible (Lenski 1987:615), because the present time has been sold under the power of evil. Landmines were everywhere and if they walked carelessly, they would suffer great losses. It is very interesting here because the word 'evil' that Paul uses is not 'kakos' but Poneroos (Ryrie 1991:282), meaning evil in the form of active resistance to good. 'These days are evil' are the days when the church is coloured by active and concrete evil actions (not just evil in the heart or evil in nature). O'Brien said evil was under the control of the ruler of the space kingdom who was against God and his will (Packer 1988:220). For this reason, believers should not just pass time but must make up for it, even learn to respect time as the most important thing in life.

\section{Redemption}

Talking about redemption is very important; it is a milestone in the history of salvation for mankind. Redemption for sins is the death of Christ who solves the problem of human sin 
and brings man into fellowship with God (Ladd 1999:167). Because the idea of redemption itself comes from God and by his grace, all humans can receive it for free.

A Chinese writer said, 'Time is something that is invisible, but so real'. As time goes by, it passes between our legs. At bedtime, time is passing around the bed. This provides us evidence that time is consciously or unconsciously being used. Martin Heidegger, one of the greatest German thinkers, said that humans must live authentically, live in time. Jean Paul Sartre goes even further to say that states of being are swallowed up by non-existence. That is, life now can enjoy everything. But one day at death, everything is over and there is nothing.

Firstly, time is something of the essence of the world that is relatively associated with human beings. In this world, nothing is eternal, only Allah because He does not need the process. He is the One who exists from eternal to eternal. In contrast, everything that is created in the world undergoes a process, and in the process we need time, that is why time is the essence of the process in the relative world.

Secondly, time is a reality that is related to space. Everything that Allah created has three of the most important elements, namely space, time and existence. Often, there are mistakes in the way of thinking of humans because they only see space as a container for accumulating property and never see time as a place for humans to be wiser again. A wise person is sensitive to time and time in a balanced space; this person will have tremendous power in his or her life (Tong 1990:31-36).

Thirdly, time has a purpose, so the objective of human life is not only to earn money and become famous, but to know Christ as Lord and Saviour and serve him by living and declaring his gospel.

\section{The concept of time management}

As long as humans live on this earth without using their time wisely, how much time is wasted? And if you want to be honest and calculative, how many hours have been wasted is a concern. Suppose the age of a human being is up to 60 years, and the person has wasted one hour every day, he or she has wasted 15695 hours or 1961 working days (1 work day = eight hours) or five more years of work in his or lifetime (i.e. if we calculate after the person has become 17 years old because under the age of 17 the person would be too young to realise the wasting of time). If the amount of time wasted for so long had been filled and utilised with useful things, it would have been very meaningful (Anwari 1984:27). It is very wise to plan the use of time carefully and to record what activities you want to do. By getting used to noting down what you want to do, it trains yourself to be even better for time management (Covey 2004:151).

People, who know how to value time and know what to do, must have an effective life purpose. Effective refers to the ability to take care, and organise one's life well and consider which things are important and which are not important (Smith 2002:9). Because in the process of being effective itself, there is a responsibility that is able to achieve the target as the final target, not just a goal. In that effectiveness, there is the power of the attitude of 'Self Control' in high discipline in using time. Life itself is getting more organised, and time is used more properly.

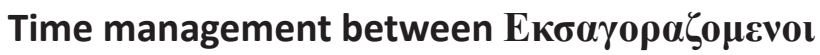

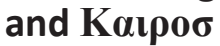

Lakein said that time is life, which cannot be changed and replaced. Wasting time means wasting your life, but controlling your time means controlling life and getting the maximum benefits (Lakein 1997:7). Good time management includes the awareness that today a person has everything at his or her disposal. The day that has passed cannot be repeated. For this reason, without managing and filling the time that goes so fast properly, it is difficult in life for someone to achieve a maximum life. So there is a waste of time and it cannot shape his or her life into a good one, because a good life starts with managing his or her time well. The more the life is shaped by time, the more alive it is.

Ephesians 5:15-17 reads: '(15) Therefore pay close attention to how you live, do not be like a fool, but be like a wise person, (16) and take advantage of the available time, for the days are evil. (17). Therefore do not be foolish, but see to it that you understand the will of the Lord'. The important words in the text are Eksagorazomenoi, Kairos and the concept of wisdom and time, and the last part is of course the conclusion of the words Eksagorazomenoi and Kairos.

In verse 15, Paul begins the verse with the word 'therefore', which is in Greek 'ouv'. The word 'ouv' clearly intends to show that the relationship of verse 15 is different from the verses before and after it. In previous chapters, Paul explained the difference between children of light who are obliged to live in love according to God's call (Eph 4:1; 5:28) and people who do not know God, namely the behaviour of the world, the flesh and the devil (Eph 4:1; 5:28, 5:17; 2:1-3) (Stoot 2003:196). After expressing the above truth, then Paul said 'because of that' he wanted to conclude and advise the congregation or believers to do something important. Paul goes on to say 'watch' carefully how you live. For the word 'Behold', he uses the Greek word 'Blepete' that is the present imperative verb. This present imperative is a command verb to continue an activity. So it can be translated as 'keep on watching' and keep paying attention. So we can see accurately the spiritual relevance of all things of value, especially those of very high value that require attention and be done carefully, accurately and closely. Paul also continues a statement 'do not be like a fool, but like a wise person' (me os asophoi). Paul meant that the church should not behave like ignorant people because in essence, they are children of light. Their life should be wise, what is meant by wise is not only knowledge but also skills in life (Lincoln 1990:341). William Dyrness defines wisdom as a very practical art to be skilled and successful in life (Dymess 2004:173). 
Stoot emphasises that a wise person has two important attitudes: (1) Wise people know very well that time is very expensive, so they do activities that have added value (value added) are eternal, and not temporary. (2) A wise person understands God's will in a way that is becoming like Christ and reading his words because God's will is in his words (2 Tm 3:15). This is done to make a person wise and stop them from sin in his or her life (Stoot 2003:197).

Paul asks believers to act wisely, to be able to see and read situations, and to know how to behave as well as to apply the knowledge they gain in their actions. They must appreciate and love the time that fills their lives with divine ethics to glorify God and try to understand God's will.

In the end Eksagorazomenoi and Kairos are said, from several meanings of the word Eksagorazomenoi, namely to redeem, even though the word redeem is used for various uses. Whether for fields or slaves, even when God saved the Israelites out of the slavery land of Egypt, the correct meaning is to redeem slaves in the market because that meaning is very precise, both from the place and the real purpose, whilst Kairos itself is the correct meaning, which is a special opportunity or time that will not be repeated because that time rarely occurs in human life. It happened once and it's a step.

\section{Wisdom as the basis of time management}

The word for wisdom in Hebrew is Hokmah for Israel. Wise is basically 'Fear of God'. Hokmah is an expression of religion that is adhered to by the Israelis. The expression of hokmah starting from the simplest religious elements is a sense of trembling before his presence and obedience to laws and worship to him. Wisdom is related to a very practical skill to act with caution, so that people are successful and not deficient in life as well as in orderly behaviour, good behaviour, and learning how to do what is good and right and fair. Wisdom is only obtained by relating to God and reading his Word, because through the Word and practice in everyday life, it will make people wise (Hill 1996:413-415).

In the New Testament, the sage is Sophia, whose roots are in Greek culture and the sage represents extraordinary abilities. The focus of his life practice is to do everything well. Wisdom speaks of combining spirituality and living practices according to the will of God Jesus Christ as a source of wisdom. Teaching and instilling the principle for humans are to learn to love enemies and bless. This teaching has a deep wisdom and meaning; how is it possible to love an enemy who hurts and to bestow blessings on him or her, but this is a reality that must be done. Herein is the love and incredible wisdom of Jesus Christ.

Verse 16 continues from verse 15, and here Paul wants to state that the concrete behaviour of believers who understand God's noble purposes is to continuously use the available time, because someone has to be right in the attitude of trying to find and do God's will. The word 'evxagorazo menoi' is a combination of evx [to leave] and agorazw [to buy or to pay for], whilst agora itself is a noun, which means market. So the noun agorazo literally means buying at the market. The word 'exagorazo' was used to redeem or pay for slaves. The prefix 'ex' according to Scott: (1) denotes great activity, which is to take all opportunities that can be taken, and (2) is a call to know oneself in the light of God's will. This is the hallmark of a wise person who lives in fellowship with God (2 Tm 2:7). The word agorazo usually means buying or paying, and it is used in the trade sector whilst buying or redeeming a slave in the market. To denote redeeming, not only the word agorazo is used, but the word 'lutrw' lutro is also used to redeem or save sinners who have been redeemed in full. Gaal also means to redeem, but what is redeemed here is not a human being, but land or fields are often used in the Old Testament (Earle 1983:321-322).

Paul insists that evil times or days are full of problems and sorrows. Paul gives further understanding that as children of God we should be able to take advantage of every opportunity and even have to buy as many opportunities as possible (Lenski 1987:615), because the present time has been sold under the power of evil. Landmines were everywhere and if they walked carelessly, they would suffer great losses. It is very interesting here because the word 'evil' used by Paul is not 'kakos', but Poneroos for evil in the form of active resistance against good (Ryrie 1991:282). By saying 'These days are evil' Paul refers the days when the church is coloured by active and concrete evil actions (not just evil in the heart or evil in nature). Brien said that evil is under the control of the rulers of the space kingdom who are against God and his will (Packer 1988:220). For this reason, believers should not just pass time but must make up for it, even learn to respect time as the most important thing in life.

So wise decisions form the basis of the time management model. Being wise makes a leader an example in all things. Stenschke (2020:10) mentions that 'ethical leaders respect others, serve others, are fair, honest and build community'.

\section{Time management as a pattern for increasing work effectiveness of contemporary Christian leaders}

A leader is someone who influences and determines the activities of others and acts to realise these activities to achieve goals. The leader has the ability to recruit, influence, instil trust and develop responsibility in others to do a certain job to achieve certain goals (Hayford 1993:42-43). But in a Christian context, Du Plessis and Nkambule (2020:8) call it 'Servant leadership as part of spiritual formation'. This leadership image serves for spiritual formation. These leaders are imprints of leaders such as Moses, David, Paul and Jesus Christ.

Maxwell said that leadership is influence (Maxwell 2001). John Robert Clinton said a leader is someone who has the capacity and responsibility given by God and who influences a group of followers towards God's plan (Clinton 2004). Thus, leadership is an art that specialises in articulating 
organisational insights and creating the conditions necessary to achieve these goals.

Orr said that a leader is someone who sets an example and has a compelling vision that transfers that vision through the influence of equipping, carrying out, training, building, challenging, motivating, empowering, energising, training, facilitating, inspiring, developing, strengthening, encouraging, enabling another person or group of people (as a team) and trying to achieve the vision, plans, goals and objectives that have been set (Orr 1998). Thus, a leader is someone who has the capacity and responsibility given by God to influence a certain group of God's people towards God's plans.

So leadership is not just an art, but a matter of influence in which there is an element of reason or science because leading what is needed is not only a beauty and power, but also a rational or scientific side. Both are very much needed in leadership.

\section{Leaders with prayer}

Leaders who pray earnestly are increasingly aware of great responsibilities and complex affairs, and a wider range of ministries demand more prayer time. In the Scriptures, prayer is often described as spiritual warfare, because of the human struggle against the governments, the authorities, the rulers of this dark world and the evil spirits in the air (Eph 6:10-18) (Octavianus 1986). Moreover, a spiritual leader must always pray so that he or she is always on the path of a relationship with God remembering that these days are evil. There is an evil power that wants to influence to sin and to trick the leaders so that their lives are no longer in accordance with God's will but are more concerned with themselves.

In Sewie Elia Huang's (2020) study of God's servants in the church, it was found that prayer, especially a fasting dissertation, had a very significant role for the growth of faith and its congregation in church growth because prayer is their intimate relationship with God and brings clarity to the way of sound spirit, so that they will be sensitive to the voice of the Holy Spirit to provide guidance to obtain spiritual and material victories.

The power of the devil is working hard to destroy the church leaders today. Many leaders are crushed and fall into sin because they don't have a regular prayer life that eventually drags them into sin. Prayer is the last bastion of defence for leaders to protect and at the same time enable them to get past the devil's traps that threaten the lives of leaders at any time.

Given the damaged and unsupportive environment, through daily prayer and fellowship a leader will be led and brought into the knowledge of God and life to please him. An absolute requirement for Christian leaders is to prioritise leadership so that it does not become arid, lacklustre and authoritative, just because it lacks prayer.
Prayer is a spiritual force that guides people to keep walking on the path of truth. Seeing the devil's tremendous ways, a consistent spiritual leader is able to increase prayer hours and arrange times for prayer. Jesus Christ Himself set the example. He got up before dawn to have an undisturbed fellowship with his father (Mk 1:35), a devotional prayer before engaging in activities. After doing activities such as healing the sick, he went to lonely places and prayed (Lk 5:16), which He performed during the day or after work.

Likewise, a spiritual leader before starting the activity gives an hour for devotional time, another one hour during the day after starting the activity and another one hour at night before bed. Thus, the stability of the leader's spiritual life is guaranteed, and the results are definitely better because the prayer life is the basis for church leaders today. Luwis said that the lifestyle of a leader who prays can be an example for his or her congregation so that the leader exhibits the character of prayer which is indispensable for human life (Luwis 2020).

\section{Leaders with working}

Because of office work that is too many and piles of pressure that is time consuming, many leaders are so crazy about work that they forget to pray and fall into the traps laid by the work schedule. But there are also leaders who are lazy at work they and do not become efficient and effective anymore, so that their work is just sitting around waiting to go home. Of course, at work, a leader must not be lazy or go crazy but must be able to streamline time. For that we need the following ways:

Firstly, planning: In principle, planning is carried out so that each activity has clear objectives and the most appropriate and efficient way to achieve the goals. In terms of time management, planning is made so that people can achieve optimal results even though they have limited and unlimited time. And in the end, planning becomes a kind of compass on which everyone bases their activities as well as like a map that provides guidance on where to go and how to get there. Seeing the usefulness of planning, the leader must take a firm stance in his or her activities so that inconsequential people also do not cause chaos in his or her activities. Something that must be considered to avoid getting stuck in a lot of activities is self-discipline.

Secondly, avoiding getting stuck in a lot of activities: Poor time management often results in time wastage, so you do not have time to stop or think about how to actually use time (Smith 2002:3). In Luke 14: 28-30, Jesus Christ Himself has proved an orderly way of working to achieve a predetermined goal. Make an agenda to record what must be done and completed in a day and how many hours must be used to complete the work. The results must be optimal because they are not disturbed by sudden activities and also those that are not important because they already have a job description for that single day that must be completed. 
Thirdly, discipline: One of the obstacles to the ineffectiveness of people managing time is lack of discipline (Wicak 2008:121). Without discipline, everything that is planned will fail, and usually people who are not disciplined have a very low level of awareness in being responsible. Discipline makes submissive and loyal to the mission and life goals that become the target.

Fourthly, priority: Priority is a tool to help organise activities based on their level of importance so that it helps to focus those that are important and postpone things that are not important. The reason is that each activity has an activity weight, and the person who prioritises correctly chooses those with high scores that must be done first.

\section{Leaders with fellowship}

Maintaining intimacy with all relationships is an absolute requirement and the main task of a leader. For this reason, Christian leaders must learn to associate with shining God's light in each of their associations because with whom to associate very much determines their value and influence on themselves. Paul advises that bad associations can spoil good habits (1 Cor 15:33).

Leaders must be selective in making friends because if they are wrong, the bad habits will transfer automatically. For this reason, leaders must limit themselves to associating with people who are not spiritual as a form of anticipation so that their lives do not become careless and degenerate spiritually. Wang said that Christian leaders are fighting against a world that is identified with all sources of evil, containing things that are evil, ugly, negative and imperfect. Instead, the leader becomes the 'salt' and 'light' of Christ to fight against the source of evil (Wang 2019).

\section{Conclusion}

Time never stops and it keeps flowing unstoppable. Time is all events that occur in the life of every human being and is also a history of the human being and of course it is a part of every human being that cannot be forgotten because it becomes a memory and a record for humans themselves.

Time management is managing time as effectively as possible in a person's life in accordance with his or her life goals. Being effective is the ability to take care of him or her, organise his or her life properly and consider which things are important and which are not important. In an effective process, it means that someone is able to manage himself in a highly disciplined manner in using time.

Being wise is to obey the corridor and to fear God in one's life is being always in his guidance. Wisdom is only obtained by relating to God and reading his Words, because practising the Word in daily life will make people wise. Wisdom speaks of combining spirituality and living practices according to the will of God Jesus Christ as a source of wisdom. One must be right in the attitude of trying to find and do God's will.
Corridor with God is the process of one's life from time to time only with God.

Wise time management is an exemplary pattern of Christian leaders towards the effectiveness of their work by using time as effectively as possible, praying, increasing the prayer hours, doing work (planning, avoiding getting trapped in many activities, discipline and priorities), increasing reading, interacting selectively and being accountable to time well.

\section{Acknowledgements Competing interests}

The authors declare that they have no financial or personal relationships that may have inappropriately influenced them in writing this article.

\section{Authors' contributions}

All authors contributed equally to this work.

\section{Ethical considerations}

This article followed all ethical standards for research without direct contact with human or animal subjects.

\section{Funding information}

This research received no specific grant from any funding agency in the public, commercial or not-for-profit sectors.

\section{Data availability}

Data sharing is not applicable to this article as no new data were created or analysed in this study.

\section{Disclaimer}

The views and opinions expressed in this article are those of the authors and do not necessarily reflect the official policy or position of any affiliated agency of the authors.

\section{References}

\footnotetext{
Anwari, M.S., 1984, Peranan Penatalayanan dalam Pengembangan Jemaat, Gandum Mas, Malang.

Barclay, W., 1983, Galatia-Efesus, BPK Gunung Mulia, Jakarta.

Barth, M.C., 1999, Tafsiran Mazmur 73-150, BPK Gunung Mulia, Jakarta.

Brown, C., 1999, The new internatinoal dictionary of the New Testamment theology, vol. 3, Zondervan Publishing House, Grand Rapids, MI.

Bruce, F.F., 1984, The New Testament international commentary on the New Testament, William B. Eerdmans, Grand Rapids, MI.

Calvin, J., 1996, Ephesians, Baker Book House, Grand Rapids, MI.

Clinton, J.R., 2004, Pembentukan Pemimpin Sejati, Metanoia, Jakarta.

Covey, S.R., 2004, The 7 habits of highly effective people, Free Press, New York, NY.

Du Plessis, A.L. \& Nkambule, C.M., 2020, 'Servant leadership as part of spiritual formation of theological students in contextualisation of 21st century theological training', HTS Teologiese Studies/Theological Studies 76(2), a5959. https://doi. org/10.4102/hts.v76i2.5959

Dymess, W., 2004, Themes in Old Testament theology, Gandum Mas, Malang.

Earle, R., 1983, Word meaning in the New Testament, Baker Book House, Grand Rapids, MI.

Harbison, F. \& Dan Myers, C., 1998, Education, manpower, and economic growth: Strategis of human resource development, McGraw Hill, New York, NY.
} 
Hayford, J., 1993, Memenangkan Masa Depan, Andi, Yogyakarta. Hill, A.E., 1996, Survei Perjanjian Lama, Gandum Mas, Malang.

Huang, S.E., 2020, 'Doa Puasa di antara Kepemimpinan Penggembalaan, Roh Kudus, dan Pertumbuhan gereja', Jurnal Excelsis Deo 4(1), 35-50. https://doi. org/10.51730/ed.v4i1.29

Ladd, G.E., 1999, Teologi Perjanjian Baru Jilid I, Yayasan Kalam Hidup, Bandung.

Lakein, A., 1997, Waktu dan Sukses, Dahara Prize, Semarang.

Lenski, R.C.H., 1987, Commentary on the New Testament, Amerika Hendriksen, s.I., MN.

Lincoln, A.T., 1990, Word biblical commentary Ephesians, Word Books Publisher, Dallas, TX.

Luwis, R.B., 2020, 'Model Pendidikan Keteladanan Kepemimpinan: Tantangan Pengembangan Sumber Daya Manusia', Jurnal Excelsior Pendidikan 2(1), 1-22. https://doi.org/10.38189/jtbh.v2i2.36

Maxwell, J.C., 2001, Developing the leader within you, Injoy, Inc., New York, NY.

Octavianus, P., 1986, Manajemen dan Kepemimpinan menurut Wahyu Allah, Yayasan Persekutuan Pekabaran Injil Indonesia, Malang.

Orr, R.A., 1998, The essential for effective Christian leadersip development, Leadership Essentials Press, Washington, DC.

Packer, J.I., 1988, New dictionary of the theology, InterVarsity Press, Leicester.
Rush, M., 2002, Manajemen menurut Pandangan Alkitab, Gandum Mas, Malang. Ryrie, C., 1991, Teologi Dasar 1, Andi Offset, Yogyakarta.

Sanders, O., 1974, Kepemimpinan Rohani, Gandum Mas, Malang.

Smith, J., 2002, Time manager Mengelola Waktu secara Efisien, Gramedia, Jakarta.

Stenschke, C.W., 2020, 'Lifestyle and leadership according to Paul's statement of account before the Ephesian elders in Acts 20:17-35', HTS Teologiese Studies/ Theological Studies 76(2), a5901. https://doi.org/10.4102/hts.v76i2.5901 Stoot, J.R.W., 2003, Efesus, Yayasan komunikasi Bina Kasih/OMF, Jakarta. Surakhmad, W., 1998, Pengantar Penelitian Ilmiah, Tarsito, Bandung. Sutedja, J.D., n.d., Diktat Pertumbuhan Gereja, GPPS, Surabaya.

Tjahyadi, S., 2008, 'Manusia dan Historitasnya menurut Martin Heidegger', Jurnal Filsafat, 18(1). https://media.neliti.com/media/publications/84925-ID-manusiadan-historisitasnya-menurut-mart.pdf.

Tong, S., 1990, Waktu dan Hikmat, Momentum, Surabaya.

Wang, S., 2019, 'Manusia dan Dunia: Konsep Kristologi dengan Perspektif reformed', Jurnal Excelsis Deo 4(1), 61-72. https://doi.org/10.51730/ed.v4i1.31

Wenham, J.W., 1977, Greek - Koine, SAAT, Malang.

Wicak, 2008, Mengelola waktu dengan Bijak, Triexs Media, Bandung.

Wiryoputro, S., 2001, The basic of Christian management, Bpk Gunung Mulia, Jakarta. 